Congress for an extra $\$ 300$ million to cover space station costs associated with the Russian delays. But members of the House of Representatives Science Committee were supportive during hearings last week.

International space agencies have been invited to participate, says Kearns, which would help defray the $\$ 100$-million cost of a typical Spacelab flight. He expects a decision to be made in a month or two, after which the research community would be notified of any new flight opportunities.

The new flights would provide a shortterm fix for space researchers, but there may be further troubles ahead. As space station managers dip into cash reserves to solve unforeseen problems, they may have to borrow again from accounts meant for developing science equipment.

In hearings last week, several members of Congress expressed concern that the science budget had been "raided" last year for nearly $\$ 500$ million. When asked if the money would be returned, NASA's head of life sciences and microgravity science, Arnauld Nicogossian, offered only vague assurances. "We believe there will be some payback of that money," he said, adding that the impact on his programme so far was "negligible" and that "we will be able to deploy most of the [science] facilities on time". That answer, responded Bud Cramer (Democrat, Alabama), “doesn't sound encouraging".

If Russia ends up defaulting altogether on building the service module, it would leave NASA without living quarters for the station's initial three-person crew. One contingency plan would be to make the US laboratory, due to be launched in 1999, habitable by adding facilities for sleeping, eating, and washing. That would mean some research facilities in the laboratory would have to be left off, to be replaced at a later date. The agency hopes it won't come to this, says one worried NASA manager. But "it's something to keep on eye on."

Tony Reichhardt

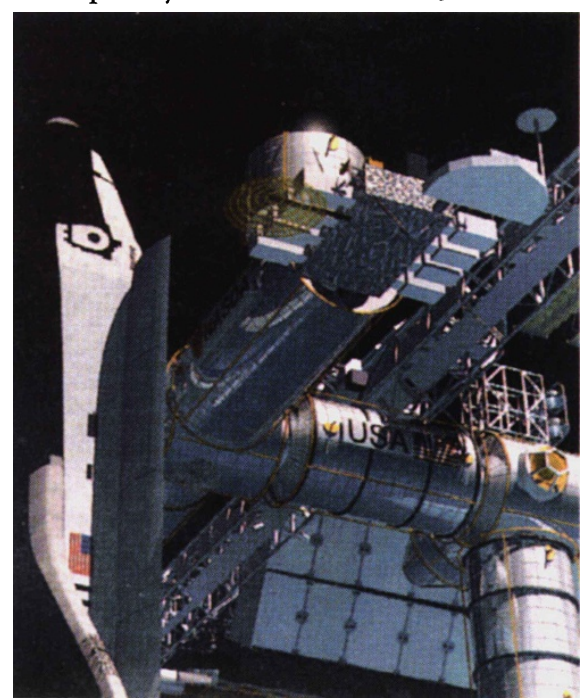

To boldly build... eventually: Delays in the space station will free up space shuttle missions.

\title{
Journals joust over policy on authors' interests
}

[WASHINGTON] A simmering dispute about the policies of journals towards the financial interests of their contributors erupted again this week with the publication in Epidemiology of an attack on the New England Journal of Medicine (NEJM) for its strict policy on this issue.

Epidemiology cited JoAnn Manson, an epidemiologist and endocrinologist at Harvard Medical School, as an innocent victim of the "police action" editorial policy of NEJM. Manson was publicly criticized by NEJM editors last autumn after she and Gerald Faich, a pharmacoepidemiologist at University of Pennsylvania Medical School, wrote an invited editorial in NEJM.

The editorial concluded that the benefits of the appetite suppressant dexfenfluramine (Redux) appeared to outweigh the risks from a rare but fatal side-effect, primary pulmonaryhypertension.

Just before publication, it was revealed in press reports that Manson had previously acted as a consultant to the drug's makers, Interneuron Pharmaceutical and Servier Amerique, and that Faich had acted as an occasional consultant to Servier since 1994. Faich had also done consultancy work during the five months before the publication of the editorial for Wyeth-Ayerst, which markets Redux in North America.

At the time, NEJM forbade editorial authors to have "ongoing financial associations (including equity interest, regular consultancies, or major research support) with a company that produces a product (or its competitor) discussed in the editorial". (The policy has since been modified, with the words "ongoing" and "regular" dropped.)

In a subsequent editorial, NEJM executive editor Marcia Angell, and its editor-in-chief, Jerome Kassirer, wrote that the "disturbing" episode showed that "there is no better demonstration of the reason for our policy than the Manson and Faich editorial".

Even if the authors' conflicts of interest had been disclosed, they wrote, "troubling questions" would have remained for readers, such as whether Manson and Faich gave enough attention to nonpharmacologic treatments of obesity in reaching their conclusions. They wrote that Faich was clearly in violation of their policy, and would not have been allowed to publish had they known of his situation. Manson, they wrote, was in a "gray area" that required further discussion between her and the NEJMeditors.

But, in next month's issue of Epidemio$\log y$, Manson defends her article as "cautiously written and... entirely independent of any influence by industry". She argues that she and Faich had been "pilloried" by NEJM editors "over what were, in essence, misunderstandings". As a result, she says, "literally hundreds" of colleagues have expressed their support and their outrage at NEJM.

She adds that she considered it a "professional and civic duty" to assent when asked in 1995 by Interneuron and Servier to testify on their behalf to a Food and Drug Administration (FDA) advisory committee reviewing the drug. Manson presented her research on body weight and mortality in women and the health risks of obesity.

In an accompanying editorial, Kenneth Rothman, the editor of Epidemiology, and Cristina Cann, associate editor, write that the NEJM is "shooting itself in the foot" by refusing to publish editorials by authors with financial connections to their subjects.

Moreover, they write, the policy's "hopeless" goal of objectivity "debases the scientific process" by replacing substantive judgements with ad hominem evaluations, a process that is "inherently irrational" and risks "smearing honest scientists".

Angell dismisses the Epidemiologyeditorial as "confused fulminations", pointing out that neither it nor Manson's article deals with Faich's role as co-author at a time when he was doing consultancy work for WyethAyerst.

She says that Manson's Epidemiologyarticle misrepresented the covering letter that accompanied the Manson-Faich editorial when it was submitted to NEJM. The letter said that "Manson and Faich participated in the FDA review of dexfenfluramine as scientific consultants on the health risks of obesity". "Do you see the mention of being a paid consultant for a company that stood to gain from the... sale of Redux?" asks Angell. "Is that a disclosure? I would think not."

Some experts say that appearances are so important that authors should disclose even one-off and financially minimal involvements. "In the public's mind - and certainly in the media's mind - it doesn't really matter whether or not the financial interests between an individual and a company were small or large," says Sheldon Krimsky, an expert in the study of scientific conflict at Tufts University in Medford, Massachusetts. "It's the principle" at stake.

But George Lundberg, editor of the Journal of the American Medical Association, rejects NEJM's "systematic exclusion" of financially interested editorial and review authors. He says that his journal's policy would have allowed "serious consideration" of publication of the Manson-Faich editorial with full disclosure.

MeredithWadman 